\title{
A COMPARATIVE ANALYSIS OF CARBON EMISSIONS IN THE ECOLOGICAL ZONES OF NIGERIA
}

\author{
Folasade Olubunmi ODERINDE* \\ Department of Geography and Environmental Management, Tai Solarin University of Education, Ijagun, Ijebu Ode, \\ Nigeria, e-mail: sadeoderinde@gmail.com
}

Citation : Oderinde, F.O. (2019). A Comparative Analysis of Carbon Emission in the Ecological Zones of Nigeria. Analele Universităţii din Oradea, Seria Geografie, 29(1), 50-59. https://doi.org/10.30892/auog.291106-793

\begin{abstract}
Carbon dioxide concentrations have risen in recent years. The increase in atmospheric carbon dioxide which has been linked to the onset of the industrial revolution has been largely responsible for the observed changes in the climate worldwide. This study examined the spatial emission of carbon from the different ecological zones in Nigeria and the relationship with vegetation health. Monthly data (January-December) of Moderate Imaging Spectroradiometer (MODIS) of Normalized Difference Vegetation Index (NDVI) and carbon data set of $500 \mathrm{~m}$ spatial resolution between year 2000 and 2012 for Nigeria were utilized for the study. The images were extracted from the archives of the National Earth Observatory. Zonal statistics of ArcGIS 10.1 software was employed to extract data of carbon emission and NDVI. Spearman's correlation analysis was used to determine the relationship between carbon emission and NDVI. The results showed that carbon emission ranged between 13.87 ppm and $256.89 \mathrm{ppm}$ with the highest found in the fresh water swamp $(142.15 \pm 60.00 \mathrm{ppm})$ and the least in sudan savanna $(108.07 \pm 29.7 \mathrm{ppm})$. The forest zones had NDVI ranging between 0.35-0.80 while savanna zone recorded between 0.16 and 0.59. Results further showed that carbon emission contributes to NDVI depletion. ( $r=-0.48, \mathrm{p}<0.05)$. Overall, there appear to be decline in vegetation health in Nigeria while the emission of carbon gradually increased during the study period. This study provides an opportunity to identify carbon sources so that adequate provision can be made for effective mitigation strategies to forestall the adverse impacts of climate change in a developing country.
\end{abstract}

Key words: Carbon emission, Vegetation, ecological zone, Nigeria, Normalized Difference Vegetation Index

$* * * * * * *$

\section{INTRODUCTION}

Human presence on earth is made possible by carbon dioxide $\left(\mathrm{CO}_{2}\right)$ and other greenhouse gases which play an important role in earth's climate. $\mathrm{CO}_{2}$ helps to stabilize the earth's temperatures to levels suitable for organic life through the greenhouse effect. Though, the increase in the concentration of greenhouse gases has been attributed as the major cause of global climate 
change which is the greatest challenge to humankind in the $21^{\text {st }}$ century,carbon dioxide is the most prevalent GHG produced by human activities (Dilmore and Zhang, 2018; Harris et al., 2017). Its concentration in the atmosphere has however been on the increase since pre-industrial times (Olivier et al., 2017; Dilmore and Zhang, 2018) with an average concentration of $403.3 \mathrm{ppm}$ in 2016 (Olivier et al., 2017). This rate of increase has also been well documented by the intergovernmental Panel on Climate Change (IPCC, 2014). Although, it has been reported that the African continent has the lowest rate of $\mathrm{CO}_{2}$ emissions (Canadell et al., 2009; Salam and Noguchi, 2005; Collier et al., 2008) but the rate of increase is above the world average and it is likely to increase in the coming years (Canadell et al., 2009; Collier et al., 2008). The major sources of carbon emission in the tropics are timber harvest, woodfuel use, tropical deforestation, forest degradation, biomass burning and wildfires (Pearson et al., 2017; Herman, 2009; Houghton, 2012; Van der Werf et al., 2003; Fearnside and Laurance, 2004; Mouillot et al., 2006; Williams et al., 2007). Nigeria is Africa's most populous country and $\mathrm{CO}_{2}$ emissions are on the increase majorly from Land use change and fossil fuels due to the rapid population growth and rapid growth in per capita GDP (Canadell et al., 2009; Momodu et al., 2011). Though, increased $\mathrm{CO}_{2}$ emissions have been reported to have positive impacts on plant productivity (Prior et al., 2011), the negative consequences are too numerous. The African continent is one of the most vulnerable regions to climate change due to the fact that her economy is exposed to the vagaries of climate (Collier et al., 2008). Climate change is already a reality in Africa and is having serious impacts on biodiversity, food security, the spread of infectious diseases and conflict in many areas (Collier et al., 2008; Willms and Werner, 2009; Sewakanmbo, 2009). There are few measurements on the carbon emission rate in Africa (Mulatu et al., 2016; MacCarthy et al., 2018). Nigeria emits $\mathrm{CO}_{2}$ and other greenhouse gases as a result of gas flaring during oil exploration. Although, there have been some studies on $\mathrm{CO}_{2}$ emissions from urban transportation, the construction industry and energy consumption due to increase in population in the country (Okelola and Okhimamhe, 2013; Edeoja and Edeoja, 2015; Adusah-Poku, 2016; Usman et al., 2017), there are very few studies on the carbon emission rate from the vegetation on which the teeming population depends on for livelihood. This study therefore attempts to investigate the carbon emission rate in the different ecological zones in the country in other to suggest effective mitigation strategies to ameliorate the adverse impacts of climate change.

\section{STUDY AREA}

Nigeria is located in the western part of Africa and is one of the largest states in the west African sub region. It is bounded by the Gulf of Guinea in the South, Cameroon and Chad in the east, Niger in the North and Benin in the west and covers an area of $923,769 \mathrm{~km}^{2}$. The country is located between latitude $4^{0}$ and $14^{0} \mathrm{~N}$ and longitude $3^{\circ}$ and $15^{\circ} \mathrm{E}$. The country has a varied topography with lowlands in the south, hills and plateau in the central part of the country, mountains in the south east and plains in the north. The climate also varies. The south and centre are tropical due to the location near the equator while the north is arid. The vegetation varies from tropical forest in the south to dry savanna in the north. The climate of the country is influenced by the Tropical Maritime (mT) air mass and the Tropical Continental (cT) air mass. The $\mathrm{mT}$ is moisture laden while the cT is dry (Iloeje, 1981). Temperature over the country varies from one place to the other.

Annual temperature of over $27^{\circ} \mathrm{C}$ is experienced in the interior while they are lower near the coast (Odekunle, 2004). Adelekan (2000) reported that the average annual temperature over the country has been increasing at a rate of $0.01^{\circ} \mathrm{C}$ annually Two main seasons are experienced in the country. These are the wet season which lasts from April to October and the dry season from November to March. Rainfall distribution is uneven and reduces as one moves towards the interior. For example, about $500 \mathrm{~mm}$ are recorded in areas in the northern fringes of the country while over $3000 \mathrm{~mm}$ are recorded for areas near the coast (Adejuwon, 1981). The climate becomes drier as one moves towards the North. The variations in the global climate are also experienced in the country's climate. 


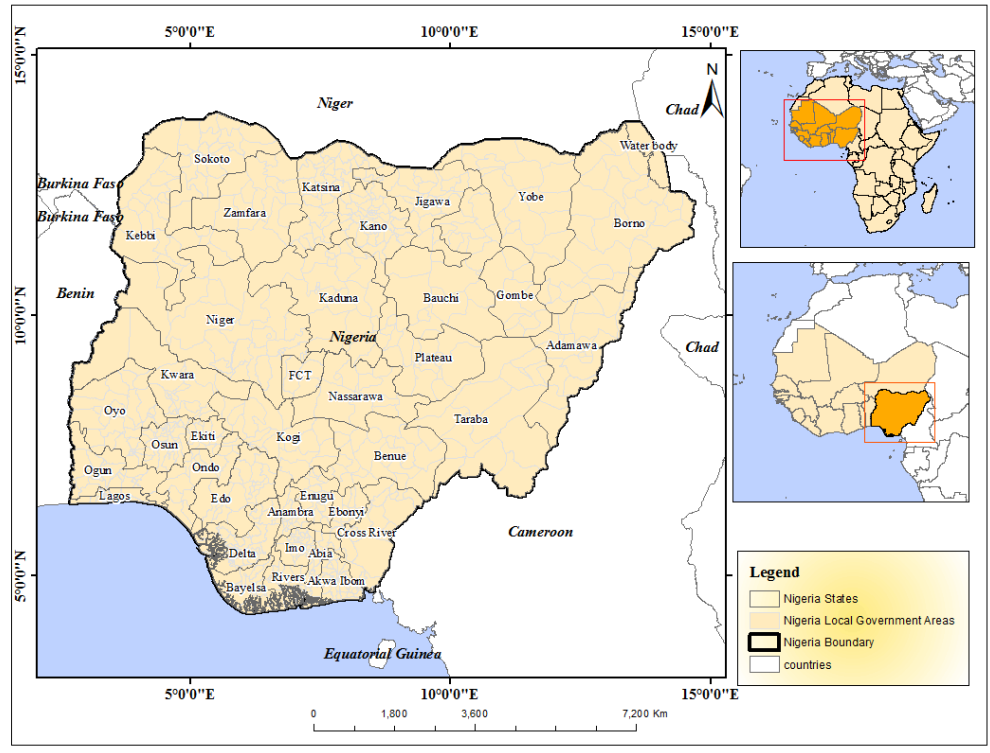

Figure 1. Study Area

\section{METHODOLOGY}

This study utilized the monthly data of MODIS (Moderate Imaging Spectroradiometer) Normalised Difference Vegetation Index (NDVI) and Carbon Data set with spatial resolution of $500 \mathrm{~m}$ by $500 \mathrm{~m}$. The MODIS carried on board Terra-Aqua and NOAA-series satellites, respectively, are cost-effective sensors, which cover the globe at least once a day. The MODIS sensor acquires data in 36 spectral bands, with variable spatial resolution of 250-1,000 meters (depending on band), in narrow bandwidths and are recorded in 12-bit format. The 36 MODIS bands which are a compromise for atmospheric, land and ocean studies, and seven bands are considered optimal for land applications (Justice et al., 2002). Composite MODIS data have a temporal resolution of 8 days and are available from 2000 onwards.

\section{PRE PROCESSING}

Preprocessing includes the derivation of maximum value composite (MVC) monthly images from original daily radiance data. The procedure of deriving monthly MVCs included the examination of daily radiance values for each wave band, together with NDVI values, for each month for each pixel. The highest daily radiance/NDVI value in a month is identified and retained. This minimizes problems of cloud impacts typical of single-date remote-sensing studies (Goward et al., 1994; Eidenshink and Faundeen, 1994). Data were further corrected for atmospheric attenuation (e.g., dust or haze, Cihlar et al., 1994), and distortions due to sun angle and satellite sensor-view angle (Kogan and Zhu, 2001; Flieig et al., 1983; Cracknell, 1997; NGDC, 1993). These satellite images were radiometrically corrected however, geometric corrections had to be done. Since the satellite imagery data set is of global coverage, Nigeria was extracted from it using the Nigeria boundary shapefile. The images were then resampled in order to ensure the resize pixel of the two dataset. Monthly images (January-December) from 2000-2012 were rescaled to get the NDVI values ranging from +1 to -1 by using the following expression:

\section{$($ NDVIi-128)*0.008}

Where, NDVIi is NDVI for the month; the entire processing of the NOAA data has been done using Idrisi Taiga 


\section{POST PROCESSING OF SATELLITE IMAGERY}

For NOAA-AVHRR, NDVI is universally defined as:

$$
\mathrm{NDVI}=\frac{\text { NIR-Red }}{\text { NIR }+ \text { RED }}
$$

Where NIR is the Near Infra red band and Red is the red band in the electromagnetic spectrum (Lillesand and Kiefer, 1994).

To derive the seasonal pattern of NDVI for 2000-2012, firstly, average NDVI for each year was computed by using the following expression:

$$
\text { Average NDVIx }=\frac{\text { JAN_NDVI }+ \text { FEB_NDVI }+\cdots \text { mmmmmm DEC_NDVI }}{12}
$$

Where, NDVIx is NDVI for y year and JAN_NDVI, FEB_NDVI..........DEC_NDVI stands for NDVI of particular months in that year.

Mean NDVI for 20 years was then computed by using the following expression:

$$
\text { Mean NDVI }=\frac{\text { Avg NDVI2000 }+ \text { AvgNDVI2001 }+\ldots \text {. AvgNDVI2012 }}{14}
$$

To derive the seasonal pattern of Carbon for 2000-2012, firstly, average NDVI for each year was computed by using the following expression:

$$
\text { Average NDVIx }=\frac{J A N_{-} C A R+F E B_{-} C A R+n_{\text {mmmmmm }} D E C_{-} C A R}{12}
$$

Where, CARx is Carbon for y year and JAN_CAR, FEB_CAR..........DEC_CAR stands for Carbon of particular months in that year.

Mean carbon for 12 years was then computed by using the following expression:

$$
\text { Mean NDVI }=\frac{\text { Avg NDVI2000 }+ \text { AvgNDVI2001 }+\ldots \text { AvgNDVI2012 }}{12}
$$

Where, Average NDVI81 Average NDVI2000 stands for the yearly average NDVI value for 12 years.

\section{ANALYSES}

Zonal statistics methods of ArcGIS 10.1 software was used to extract the NDVI values and carbon emission values in different ecological zones of Nigeria. A correlation and regression analysis was further carried out to observe the strength of the relationship between carbon emission and NDVI. Data were presented in tables and maps.

\section{RESULTS AND DISCUSSION}

Table 1 presents the carbon emissions and NDVI values from the different ecological zones. The result shows that carbon emission from the different ecological zones ranged between $13.87 \mathrm{ppm}$ and $256.89 \mathrm{ppm}$ during the study period. The minimum emission rate was observed in the lowland rainforest with a mean value of $114.81 \pm 42.1 \mathrm{ppm}$ while the maximum was from the freshwater swamp forest with a mean value of $142.15 \pm 60.00 \mathrm{ppm}$. The high rate of carbon emission in the freshwater swamp forest may be as a result of warm temperatures. Sjogersten et al., (2014) reported increased carbon dioxide emissions from tropical wetlands. Hu et al., (2016) 
also noted that hydrological factors could be important in the emission of $\mathrm{CO}_{2}$. Futhermore, the mineralization of organic carbon occurs as a result of the ability of microbes to survive in flooded areas which in turn distrupts soil microbial respiration. The low emission rate from the lowland forest may be attributed to the fact that the area is composed of diverse trees because Montagnin and Nair (2004), reported that trees are known to have a great potential of storing carbon in their biomass. Previous studies have revealed that the tropical forests are an important carbon sink (Pan et al., 2011) and that forests can play a major role in climate change through carbon sequestration or emission (Sedjo and Sohngen, 2012). Thus, the role of tropical forests is critical in the global carbon cycle. Reduction in emissions is a way of combating climate change. The result also shows that the NDVI value for the ecological zones range between 0.16 and 0.80 . The highest NDVI value was recorded in the Lowland rainforest with a mean value of $0.56 \pm 0.14$ while the lowest value was recorded in the Sahel savanna with a mean of $0.26 \pm 0.1$. The high NDVI value recorded in the Lowland rainforest indicates very healthy vegetation and a high density of green vegetation. This may be attributed to the receipt of high precipitation. This indicates that green vegetation signifies a higher photosynthetic activity and vigour (Banan et al., 1995). The low NDVI value recorded in the Sahel savanna, Sudan savanna and Guinea savanna can be attributed to the low amount of rainfall received in this area which is in line with the findings of Meneses-Tovar (2011). Studies in other parts of the savanna in Africa also noted the relationship between precipitation and NDVI (Chamaille-James and Fritz, 2009). Vegetation blossoms where environmental conditions are favourable.The freshwater swamp forest was also observed to have average NDVI values probably due to the waterlogged nature of the area.

Table 1. Minimum, Maximum and Mean Carbon Emissions and NDVI in Different Ecological Zones in Nigeria

\begin{tabular}{|l|l|l|}
\hline \multicolumn{3}{|c|}{ Carbon Emissions (ppm) } \\
\hline Ecological Zones & Minimum-Maximum & Mean \pm SD \\
\hline Lowland Rainforest & $13.87-199.61$ & $114.81 \pm 42.1$ \\
\hline Sahel savanna & $99.87-120.95$ & $109.71 \pm 5.9$ \\
\hline Guinea savanna & $101.19-121.94$ & $112.37 \pm 6.4$ \\
\hline Freshwater swamp & $89.76-256.89$ & $142.15 \pm 60.0$ \\
\hline Derived savanna & $75.59-241.83$ & $129.36 \pm 53.1$ \\
\hline Sudan savanna & $73.82-156.46$ & $108.07 \pm 29.7$ \\
\hline \multicolumn{2}{|c|}{ NDVI } \\
\hline Ecological zones & Minimum-Maximum & Mean \pm SD \\
\hline Lowland Rainforest & $0.35-0.80$ & $0.56 \pm 0.14$ \\
\hline Sahel savanna & $0.16-0.40$ & $0.26 \pm 0.1$ \\
\hline Guinea savanna & $0.18-0.55$ & $0.33 \pm 0.1$ \\
\hline Freshwater swamp & $0.41-0.65$ & $0.52 \pm 0.1$ \\
\hline Derived savanna & $0.23-0.59$ & $0.43 \pm 0.1$ \\
\hline Sudan savanna & $0.19-0.51$ & $0.32 \pm 0.1$ \\
\hline
\end{tabular}

Table 2 presents the monthly carbon emission rate and NDVI values during the study period. The emission rate ranged between $73.82 \mathrm{ppm}$ and $256.89 \mathrm{ppm}$. The lowest emission rate was observed in the month of August with a mean value of $111.13 \pm 20.41 \mathrm{ppm}$ while the maximum rate was recorded in January with a mean value of $165.91 \pm 66.97 \mathrm{ppm}$. The high rate of carbon emission observed in the month of January may be due to bush burning and other land cover changes which are prevalent during the dry season in many parts of the country as farmers clear and prepare their farmlands in anticipation of the rains which signifies the beginning of the planting season. Thus, the human activities during this period always make a substantial amount of carbon to be released into the atmosphere. Appiah et al., (2018) noted that bush burning constitutes a challenge to farming and thus a cause of climate variability and climate change. As 
the $\mathrm{CO}_{2}$ concentration grows, it increases the radiative forcing of the atmosphere, warming the planet. The low amount of carbon emitted in the month of August may be related to the growing season when plants absorb $\mathrm{CO}_{2}$ from the atmosphere. This may also be due to a low ratio of photosynthesis to respiration which can be attributed to the fact that higher $\mathrm{CO}_{2}$ enables plants to grow faster. The monthly NDVI value during the study period ranged between 0.16 and 0.80 . The lowest value was observed in the month of April with a mean value of $0.42 \pm 0.28$ while the highest value was also recorded in the month of April with a mean value of $0.42 \pm 0.28$. The low and high NDVI observed in the month of April is an indication that there is a large range in vegetation health. This may also be attributed to the fact that the plants respond differently to weather change. This means that there are very healthy and very poor plants.

Table 2. Minimum, Maximum and Mean Monthly carbon emissions and NDVI in Nigeria

\begin{tabular}{|l|l|l|}
\hline \multicolumn{3}{|c|}{ Carbon emissions(ppm) } \\
\hline Month & Minimum-Maximum & Mean \pm SD \\
\hline January & $110.55-256.89$ & $165.91 \pm 66.97$ \\
\hline February & $101.19-242.72$ & $152.49 \pm 58.76$ \\
\hline March & $105.81-162.99$ & $129.49 \pm 21.40$ \\
\hline April & $90.94-132.87$ & $114.13 \pm 15.24$ \\
\hline May & $92.13-132.58$ & $108.05 \pm 14.52$ \\
\hline June & $82.11-116.93$ & $100.79 \pm 14.79$ \\
\hline July & $78.99-118.70$ & $104.99 \pm 15.79$ \\
\hline August & $73.82-127.56$ & $111.13 \pm 20.41$ \\
\hline September & $74.30-121.95$ & $97.16 \pm 17.82$ \\
\hline October & $75.59-115.10$ & $93.06 \pm 14.16$ \\
\hline November & $110.09-139.25$ & $121.99 \pm 9.94$ \\
\hline December & $99.87-199.61$ & $152.82 \pm 45.23$ \\
\hline \multicolumn{2}{|c|}{ NDVI } & \\
\hline Month & Minimum-Maximum & Mean \pm SD \\
\hline January & $0.20-0.60$ & $0.35 \pm 0.16$ \\
\hline February & $0.19-0.52$ & $0.32 \pm 0.15$ \\
\hline March & $0.17-0.51$ & $0.31 \pm 0.14$ \\
\hline April & $0.16-0.80$ & $0.42 \pm 0.28$ \\
\hline May & $0.18-0.67$ & $0.41 \pm 0.23$ \\
\hline June & $0.27-0.58$ & $0.41 \pm 0.13$ \\
\hline July & $0.30-0.59$ & $0.40 \pm 0.09$ \\
\hline August & $0.23-0.54$ & $0.41 \pm 0.11$ \\
\hline September & $0.35-0.55$ & $0.45 \pm 0.07$ \\
\hline October & $0.34-0.73$ & $0.51 \pm 0.13$ \\
\hline November & $0.27-0.64$ & $0.45 \pm 0.14$ \\
\hline December & $0.24-0.62$ & $0.39 \pm 0.15$ \\
\hline & & \\
\hline & & \\
\hline
\end{tabular}

Table 3 presents the annual rate of carbon emission and NDVI during the study period. The emission rate ranged between $99.20 \mathrm{ppm}$ and $120.03 \mathrm{ppm}$. It was observed that year 2001 had the least rate of emission of $\mathrm{CO}_{2}$ with a mean value of $100.68 \pm 1.71 \mathrm{ppm}$ while the highest rate of emission was recorded in year 2007 with a mean value of $118.28 \pm 1.22 \mathrm{ppm}$. This shows that the rate of emission increased steadily from the beginning of the study period until it reached a peak in year 2007. This also corroborates the report of authors that the rate of carbon emission is reported to be on the increase globally (Friedlingstein et al., 2014; Raupach et al., 2007; Olivier et al., 2017). The emission rate reduced slightly after year 2007. This may be attributed to the awareness being created on the impact of increased $\mathrm{CO}_{2}$ in the atmosphere. The table also shows the NDVI values during the study period which range between 0.37 and 0.40 . The minimum values were observed in year 2001, 2011 and 2012 with a mean value of $0.37 \pm 0.00$ while the highest values 
were recorded in year 2003 and 2007 with a mean value of $0.39 \pm 0.00$. The result shows that the vegetation health is poor during the study period as the values are below 0.5. This may be attributed to changing precipitation pattern in the country and land use/land cover changes as a result of increase in population. Fashae et al., (2017) noted the relationship between precipitation and NDVI in the country.

Table 3. Minimum, Maximum and Mean Annual carbon emissions and NDVI in Nigeria

\begin{tabular}{|c|c|c|}
\hline \multicolumn{3}{|c|}{ Carbon emissions (ppm) } \\
\hline Year & Minimum-Maximum & Mean \pm SD \\
\hline 2000 & $108.78-110.06$ & $109.73 \pm 0.63$ \\
\hline 2001 & $99.20-102.38$ & $100.68 \pm 1.71$ \\
\hline 2002 & $113.48-116.82$ & $114.46 \pm 1.58$ \\
\hline 2003 & $115.29-118.64$ & $116.55 \pm 1.61$ \\
\hline 2004 & 106.49-109.98 & $107.57 \pm 1.65$ \\
\hline 2005 & $106.37-108.18$ & $107.11 \pm 0.89$ \\
\hline 2006 & $107.89-108.87$ & $108.18 \pm 0.47$ \\
\hline 2007 & $117.43-120.03$ & $118.29 \pm 1.23$ \\
\hline 2008 & $113.52-116.06$ & $114.53 \pm 1.24$ \\
\hline 2009 & $106.73-108.85$ & $107.56 \pm 1.03$ \\
\hline 2010 & $104.88-112.56$ & $107.69 \pm 3.49$ \\
\hline 2011 & $100.77-110.94$ & $104.59 \pm 4.49$ \\
\hline 2012 & $100.42-110.08$ & $104.36 \pm 4.69$ \\
\hline \multicolumn{3}{|c|}{ NDVI } \\
\hline Year & Minimum-Maximum & Mean \pm SD \\
\hline 2000 & $0.38-0.38$ & $0.38 \pm 0.00$ \\
\hline 2001 & $0.37-0.37$ & $0.37 \pm 0.00$ \\
\hline 2002 & $0.39-0.39$ & $0.39 \pm 0.00$ \\
\hline 2003 & $0.39-0.40$ & $0.39 \pm 0.00$ \\
\hline 2004 & $0.38-0.38$ & $0.38 \pm 0.00$ \\
\hline 2005 & $0.38-0.38$ & $0.37 \pm 0.00$ \\
\hline 2006 & $0.38-0.38$ & $0.38 \pm 0.00$ \\
\hline 2007 & $0.40-0.40$ & $0.39 \pm 0.00$ \\
\hline 2008 & $0.39-0.39$ & $0.39 \pm 0.00$ \\
\hline 2009 & $0.38-0.38$ & $0.38 \pm 0.00$ \\
\hline 2010 & $0.38-0.39$ & $0.38 \pm 0.01$ \\
\hline 2011 & $0.37-0.38$ & $0.37 \pm 0.01$ \\
\hline 2012 & $0.37-0.38$ & $0.37 \pm 0.01$ \\
\hline
\end{tabular}

Figure 2 presents the correlation between carbon and NDVI. The line equation is given as $\mathrm{y}=-301.9 \mathrm{x}+242.85$. The $\mathrm{R}^{2}$ value is given as 0.4886 . This indicates that carbon emission contributes about $48 \%$ to NDVI depletion in the study area, provided all other factors remain constant as noted by Krakauer et al., 2017. The rate of depletion of NDVI is given as 301.9 and at $242.85 \mathrm{ppm}$, NDVI would totally collapse which means it will become zero (0). 


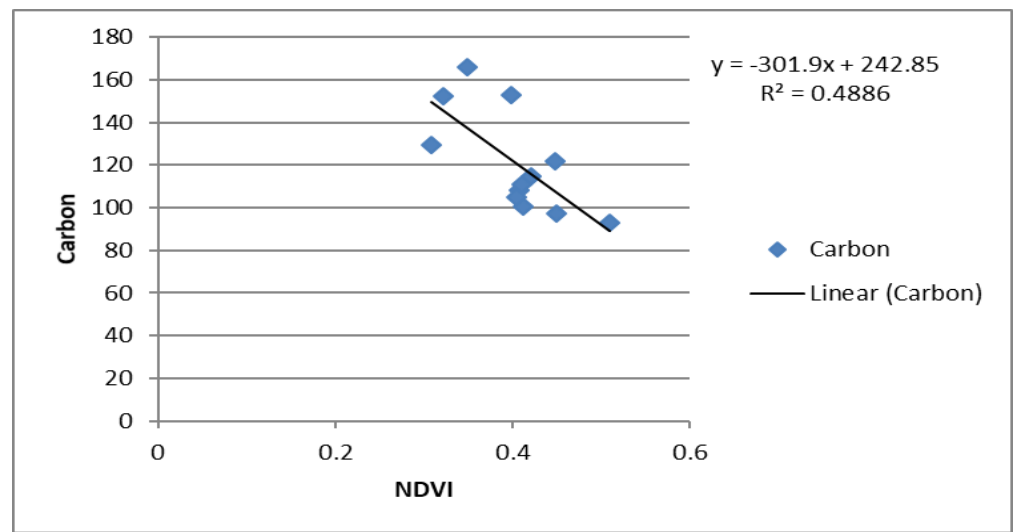

Figure 2. Correlation between NDVI and Carbon emission

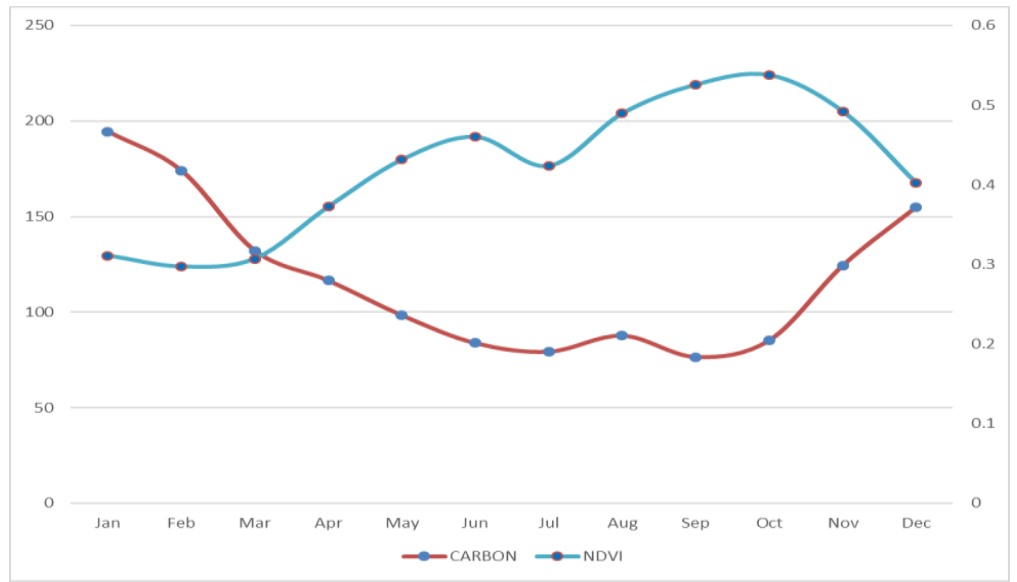

Figure 3. Monthly relationship between carbon emissions and NDVI

Figure 3 presents the monthly relationship between carbon emission and NDVI during the study period. An inverse relationship was observed from the figure. The highest carbon emission was experienced in January which coincides with the period of the lowest NDVI value. The lowest carbon emission was observed in the month of September which is also the month when NDVI was the highest. This relationship could be as a result of the fact that vegetation serves as a major sink of atmospheric carbon (Gibbs et al., 2007; Sedjo and Sohngen, 2012).

\section{CONCLUSION}

The study has shown that carbon emission rate is related to the vegetation type and the activities being carried out in each ecological zone. The emissions were also observed to be higher in the months of January, February and March and lower in the other months of the year. Vegetation health was also observed to be related with the climate and a general decline was observed during the study period. Carbon emission and NDVI were found to be inversely related while carbon emission was also observed to be a major contributor to the decline of the NDVI. The need to identify the various sources of carbon dioxide to the atmosphere in different ecosystems is necessary due to the increase in the rate of its emission. This will enable concerted efforts to be focused towards its reduction by adopting effective strategies that would forestall the adverse impacts especially in developing countries where the consequences are severe and the adaptive capacities are lacking. 


\section{REFERENCES}

Adejuwon, J.O. (1981). Fuelwood in tropical ecological. In Afolabi-Ojo, G.J.A., Morgan, W.B and Moss, R.P. (Eds.) Rural Energy in Southwestern Nigeria: A preliminary Report-Proceedings of the second Ife workshop. Tokyo. Japan: United Nations University.

Adelekan, I.O. (2000). A survey of rainstorms as weather hazards in Southwestern Nigeria. The Environmentalist, 20(1): 33-39.

Adusah-Poku, F. (2016). Carbon dioxide emissions, urbanization and population: Empirical evidence in Sub-saharan Africa. Energy Economics Letters, 3(1): 1-16.

Appiah,D.O.,Akondoh,A.C.K.,Tabiri,R.K and Donkor,A.A.(2018). Smallholder farmers' insight on climate change in rural Ghana.Cogent Food and Agriculture, 4:1436211

Banan, A., Morin, D., \& Bonn, F.A. (1995). A review of vegetation indices. Remote Sensing of Environment, 13: 95-120.

Canadell, J.G., Raupach, M.R., Houghton, R.A. (2009). Anthropogenic $\mathrm{CO}_{2}$ emissions in Africa. Biogeosciences, 6:463-468.

Chammaille-James, S., \& Fritz, A. (2009). Precipitation-NDVI relationships in eastern and southern African savannas vary along a precipitation gradient. International Journal of Remote Sensing, 30(13): 3409-3422.

Cihlar, J., Manak, D., \& D'lorio M. (1994). Evaluation of composting algorithms for AVHRR data over land. IEEE Transactions. Geosciences Remote Sensing, 32:427-437.

Collier, P., Conway, G., \& Venables, T. (2008). Climate Change and Africa. Oxford Review of Economic Policy, 24(2): 337-353.

Cracknell, A.P. (1997). The advanced very high resolution radiometer. London: Taylor and Francis.

Dilmore, R., \& Zhang, L. (2018). Greenhouse gases and their role in Climate Change. in: Romanov V. (Ed.), Greenhouse Gases and Clay Minerals, Green Energy and Technology, Springer, USA, pp. 15-32.

Edeoja, J.A., \& Edeoja, A.O. (2015). Carbon Emission Management in the Construction Industry - Case studies of Nigerian Construction Industry. American Journal of Engineering Research, 4(7): 112-122.

Eidenshink, J.C., \& Faudeen, J.L. (1994). IKM AVHRR global land data set: first stages in implementation. International Journal of Remote Sensing, 15(17): 3443-3462.

Fashae, O., Olusola, A., \& Adedeji, O. (2017). Geospatial analysis of changes in vegetation over Nigeria. Bulletin of Physical Geography series, 13:17-28.

Fearnside, P.M., \& Laurance, W.F. (2004). Tropical Deforestation and Greenhouse-Gas Emissions. Ecological Applications, 4(4): 982-986.

Flieig, A.J., Heath, D.F., Klenk, K.F., Oslik, N., Lee, K.D., Park, H., Bartia, P.K., \& Gordon, D. (1983). User's guide for the solar Backscattered ultraviolet (SBUV) and total ozone mapping Spectroradiometer(TOMS) RUT-S and RUTT data sets. October 31, 1978-November 1980. NASA Reference Publication 1112.

Friedlingstein, P., Andrew, R.M., Rogej, J., Peters, G.P., Canadell, J.G, Knutti, R, Luderer, G., Raupach, M.R., Schaeffer, M., Van Vuuren, D.P., \& Le Quere, C. (2014). Persistent growth of $\mathrm{CO}_{2}$ emissions and implications for reaching climate targets. Nature Geoscience, 7:709-715.

Gibbs, H.K., Brown, S., Niles, O.J., \& Foley, J.A. (2007). Monitoring and estimating tropical forests carbon stocks: Making REDD a reality. Environmental Research Letters, 2:1-13.

Goward, D.G., Turner, S., Dye, D.G., \& Liang, J. (1994). University of Maryland improved global vegetation index. International Journal of Remote Sensing, 15:3365-3395.

Harris, J.M., Roach, B., \& Codur, A. (2017). The economics of Global Climate Change. Global Development and Environment Institute, Tufts University, USA.

Herman, G. V. (2009). Omul şi modificările antropice din Câmpia Someşului [The man and anthropogenic changes in Somes Plain], Editura Universității din Oradea, Oradea, Romania.

Houghton, R.A. (2012). Carbon emissions and the drivers of deforestation and degradation in the tropics. Current Opinion in Environmental Sustainability, 4:597-603.

Hu, M., Ren, H., Ren, P., Li, J., Wilson, B.L., \& Tong, C. (2016). Response of gaseous carbon emissions to low-level salinity increase in tidal marsh ecosystem of the Min River estuary, Southeastern China. Journal of Environmental Sciences, 52:210-222.

Iloeje, N.P. (1981). A New Geography of Nigeria, Longman: UK

IPCC, 2014. Summary for Policymakers, In Climate Change 2014: in Edenhofer, O.R., Pichs-Madruga, Y., Sokona, E., Farahani, as., Kadner, K., Seyboth, A., Adler, I., Baum, S., Brunner, P., Eickesneier, B., Kriemann, J., Savolainen, S., Schlomer, C., Von Stechow, T., Zwickel and J.C Minx (Eds.), Mitigation of Climate Change: Contribution of Working group 111 to the Fifth Assessment Report of the Intergovernmental Panel on climate change Cambridge University Press, Cambridge, United Kingdom and New York, NY, USA, pp 1-30.

Justice, C.O., Townshend, J.R.G., Vermote, E.F., Masuoka, E., Wolfe, R.E., Saleous, N., Roy, D.P., \& Morisete, J.T. (2002). An Overview of MODIS Land Data Processing and Product status. Remote Sensing of Environment, 83:3-15.

Kogan, F.N., \& Zhu, X. (2001). Evolution of long term errors in NDVI time series: 1985-1999. Advances in Space Research, 28:149-153.

Krakauer, N.Y., Lakhankar, T., \& Anadon, J.D. (2017). Mapping and attributing normalized difference vegetation index trends for Nepal. Remote Sensing, 9, doi: 10.3390/rs9100 986

Lillesand, T.M., \& Kiefer, W. (1994). Remote sensing and Image Interpretation. John wiley and Sons, New York, USA.

MacCarthy, D.S., Zougmore, R.B., Akponikpe, P.B.I., Koomson, E., Savadogo, P., \& Adiku, S.G.K. (2018). Assessment of 
Greenhouse Gas Emissions from Different Land use Systems. A case study of $\mathrm{CO}_{2}$ in the Southern Zone of Ghana. Applied and Environmental Soil Science, 2018: 1-12.

Meneses-Tovar, C.L. (2011), NDVI as indicator of degradation. Unasylva, 238, 62:39-46.

Momodu, A.S., Siyanbola, W.O., Pelemo, D.A., Obioh, I.B., \& Adesina, F.A. (2011). Carbon Flow Pattern in the forest zones of Nigeria as influenced by Land use Change. African Journal of Environmental Science and Technology, 5(9): 700-709.

Montagnin, F., \& Nair, P.K.R. (2004). Carbon Sequestration: An underexploited environmental benefit of agroforestry systems. Agroforestry Systems, 61:281-295.

Mouillot, F., Narasimha, A., Balkansi, Y., Lamarque, J., \& Field, C.B. (2006). Global Carbon emissions from biomass burning. Geophysical Research Letters, 33(1):1-4

Mulatu, D.W., Eshete, Z.S., \& Gatiso, T.G. (2016). The Impact of $\mathrm{CO}_{2}$ on Agricultural Productivity and Household welfare in Ethiopia: A comparative General Equilibrium Analysis. Environment for Development Discussion Paper Series. online available at www.efdinitiative.org/sites/default/files/publications/efd-16-08

NGDC (National Geophysical Data Center). (1993). 5 minute gridded world elevation. NGDC data announcement DA 93MG G-01.Boulder, USA.

Odekunle, T.O. (2004). Rainfall and the length of the growing season in Nigeria. International Journal of Climatology, 24: 467-479.

Okelola, O.F., \& Okhimamhe, A. (2013). Vehicular carbon emissions concentration level in Minna, Nigeria: The Environmental Cum Climate Change Implication. African Technology Policy Studies Network, Working paper Series NO.71, Nairobi, Kenya.

Olivier, J.G.J., Schure, K.M., \& Peters, J.A.H.W. (2017). Trends in Global $\mathrm{CO}_{2}$ and Total Greenhouse Gas Emissions. Environmental Assessment Agency, The Hague, Netherlands.

Pan, Y., Birdsey, R.A., Fang, J., Houghton, R., Kauppi, P.E, Kurtz, W.A., \& Phillips, O.L. (2011). A large and persistent Carbon sink in the World's forests. Science, 333:988-993.

Pearson, T.R.H., Brown, S., Murray, L., \& Sidman, G. (2017). Greenhouse gas emissions from tropical forest degradation: an underestimated source. Carbon Balance and Management, 12(3): Doi 10.1186/s 1302-017-0072-2.

Prior, S.A., Runion, G.B., Marble, S.C., Rogers, H.H., Gilliam, C.H., \& Torbert, H.A. (2011). A review of elevated Atmospheric $\mathrm{CO}_{2}$ Effects on plant growth and water Relations: Implications for Horticulture. Hortscience, 46(2): 158-162.

Raupach, M.R., Marland, G., Cias, P., Le Quere, C., Canadell, J.G., Klepper, G., \& Field, C.B. (2007). Global and regional drivers of accelerating $\mathrm{CO}_{2}$ emissions. Proc.Natl.Acad.Sci. 104(24): 10288-10293.

Salam, M.A., \& Noguchi, T. (2005). Impact of Human Activities on Carbon Dioxide $\left(\mathrm{CO}_{2}\right)$ Emissions: A statistical Analysis. Environmentalist, 25(1): 19-30.

Sedjo, R., \& Sohngen, B. (2012). Carbon Sequestration in Forests and Soils. Annual Review of Resource Economics, 4: 127-144.

Sewakanmbo, N, K. (2009). Climate Change and Health: An issue with great potential for exacerbating health inequities in Africa, in Besada and Sewankambo (Eds). Climate change in Africa, Mitigation and Governance Challenges. The Centre for International Governance Innovation (CIGI), Waterloo, Ontario, Canada, pp.16-20.

Sjogersten, S., Black, C.R., Evers, S., Hoyos-Santillan, J., Wright, E.L., \& Turner, B.L. (2014). Tropical wetlands: A missing link in the global carbon cycle? Global Biogeochemical cycles, 28 (12): 1371-1386.

Usman, S.U., Abdulhamid, A.I., Gwadabe, S., Usman, A.K., Isah, B., \& Mallam, I. (2017). Urbanization and climate change: The role of transport in carbon dioxide emission in Kano metropolis, Nigeria. Bayero journal of Pure and Applied Sciences, 10(1): 536-540.

Van der werf, G.R., Randerson, J.T., Gollatz, G.J., \& Giglio, L, (2003). Carbon emissions from fires in tropical and subtropical ecosystems. Global Change Biology, 9:547-562.

Williams, C.A., Hanam, N.P., Neff, J.C., Scholes, R.J., Berry, J.A., Denning, A.S., \& Baker, D.F. (2007). Africa and the global carbon cycle. Carbon Balance and Management, 2(3):doi:10.1186/1750 - 0680-2-3.

Willms, D.G., \& Werner, K. (2009). Climate Change and Conflict in Africa. in Besada H., Sewakanmbo N.K. (Eds.) Climate Change in Africa, Mitigation and Governance Challenges. The Centre for International Governance Innovation (CIGI), Waterloo, Ontario, Canada, pp 26-30.

Submitted:

September 02, 2018
Revised:

February 08, 2019
Accepted and published online March 19, 2019 